\title{
Managing Water Scarcity at a River Basin Scale with Economic Instruments
}

\author{
Carlos Mario Gómez Gómez*,†,\|, C. D. Pérez-Blanco*, \\ David Adamson" and Adam Loch" \\ *Department of Economics, Universidad de Alcalá \\ Alcalá de Henares, Spain \\ †Madrid Institute for Advanced Studies in Water Technologies \\ (IMDEA-Water) Alcalá de Henares, Spain \\ Centro Euro-Mediterraneo sui Cambiamenti \\ Climatici (CMCC), RAAS Division \\ Isola di San Giorgio Maggiore, 8. 30124 Venice, Italy \\ ${ }^{\S}$ Fondazione Eni Enrico Mattei (FEEM) \\ Isola di San Giorgio Maggiore, 8. 30124 Venice, Italy \\ "Centre for Global Food and Resources \\ The University of Adelaide, Adelaide, Australia \\ Imario.gomez@uah.es \\ Received 14 November 2016 \\ Revised 14 March 2017 \\ Accepted 26 March 2017 \\ Published 19 May 2017
}

This paper presents a conceptual framework for both assessing the role of economic instruments, and reshaping them in order to enhance their contribution to the goals of managing water scarcity. Water management problems stem from the mismatch between a multitude of individual decisions, on the one hand, and the current and projected status of water resources on the other. Economics can provide valuable incentives that drive individual decisions, and can design efficient instruments to address water governance problems in a context of conflicting interests and relevant transaction costs. Yet, instruments such as water pricing or trading are mostly based on general principles of welfare economics that are not readily applicable to assets as complex as water. A flaw in welfare economic approaches lies in the presumption that economic instruments may be good or

"Corresponding author.

This is an Open Access article published by World Scientific Publishing Company. It is distributed under the terms of the Creative Commons Attribution 4.0 (CC-BY) License. Further distribution of this work is permitted, provided the original work is properly cited. 
bad on their own (e.g., finding the "right" price). This vision changes radically when we focus on the problem, instead of the instrument. In this paper, we examine how economic instruments to achieve welfare-enhancing water resource outcomes can realize their full potential in basin-scale management contexts. We follow a political economy perspective that views conflicts between public and private interest as the main instrumental challenge of water management. Our analysis allows us to better understand the critical importance of economic instruments for reconciling individual actions towards collective ambitions of water efficiency, equity and sustainability with lessons for later-adopting jurisdictions. Rather than providing panaceas, the successful design and implementation of economic instruments as key river basin management arrangements involves high transaction costs, wide institutional changes and collective action at different levels.

Keywords: Economic instruments; river basin management; political economy; water policy.

\section{Introduction}

A global imbalance between the supply of and demand for water resources is being increasingly realized under population growth pressures, changing distributions of wealth and consumption, and adverse climatic events (OECD 2015). This has resulted in future water crises being consistently identified as the single greatest global social threat in terms of impact (WEF 2017). Addressing this threat will require water managers to rebalance water resource use across groups including urban towns and cities, industrial and mining businesses, agricultural farms and ecosystems. Inequitable utilization of water resources can harm downstream groups in a river basin via diminished and unreliable water supplies and decreased water quality (Quiggin 2001). Rebalancing water-use between groups is complicated by fundamental welfare questions raised by Hicks (1939), Kaldor (1939) and Pigou (1932) on how to reallocate resources such that we minimize harm and maximize the benefits from their changed use.

Water reallocation is thus a complex issue. Political institutions, the framework of laws and customs in which they operate, and the distribution of political power in economic policy making also shape the transaction costs of reallocation and the range of policies that can be implemented. Diverse methods have been applied to this issue over the last 150 years. Before concerns about the limited nature of water resources became commonplace, water management priorities focused on mobilizing and/or adapting supply to relevant uses and places through engineering projects (Dinar and Saleth 2005). Water engineering has played a progressive and integral part of many countries' economic development (Grey and Sadoff 2007; Hall et al. 2014), with economic benefits often used to secure the significant funding associated with the supply-based projects. Matching supply and demand in a growing economy has thus made investment in water an important driver of 
economic development. Benefits are taken for granted, subsidies may be viewed as beneficial for competitiveness and growth and, besides covering financial needs, cheap water is considered desirable on equity and progressive grounds.

However, water demand often grows (significantly) above the combined supply capacity of natural and man-made capital. Institutional dynamics and information constraints, coupled with uncertain water supply as a result of climate change and growing environmental concerns, may lead to short-term solutions involving water over-allocation (Vörösmarty et al. 2010). Eventually, low-social-cost options for impounding water will be exhausted (Randall 1981), and institutional tippingpoints increasingly exposed by droughts and other climate extremes. This will exacerbate structural problems and social conflicts, and policy priorities will shift away from promoting simultaneous development in different areas of the economy. Instead, policy focus will turn to making use of water in a sector/place compatible with: (i) the resources available in the short-term; and (ii) those resources likely to be available in the longer-term - a process that is known as river basin closure (Falkenmark and Molden 2008). Recognition of the complex interaction between, and interdependence across, multiple water-user groups has in turn prompted the adoption of integrated water resource management arrangements in many developed contexts. Integrated management arrangements often highlight the need for wider planning and data collection in many areas to support and deliver water (re)allocation to meet collective (common-good) objectives. In recent decades, it has been argued that the best way to achieve these collective objectives is through economic instruments such as water pricing/charges, cooperative agreements and market-based transfers (Lago et al. 2015). Water management economic instruments thus go beyond incentives to penalize/reward individual behavior: the distinctive characteristics of the resource call for cooperation between local, regional and national groups of interest, including public institutions. Consequently, while methods for managing water can be thought of as having become increasingly focused over time, the scale of water resource management has grown exponentially away from simple supply-oriented operations to basin-wide dimensions involving multiple jurisdictions, users and complex management arrangements.

Ideally, economic instruments in water are designed to facilitate the establishment, or overcome barriers to the formation, of functioning trades. Properly implemented, economic instruments can serve to coordinate water decisions and align them with social interests or goals (e.g., reallocation of water to the environment). However, this requires purposely designed instruments that harmonize individual decision outcomes with complete water policy objectives (Lago et al. 2015). Traditional harmonization approaches have typically provided inadequate signals for changing people's decisions so that they contribute to collective 
objectives such as efficiency, equity and sustainability at a river basin scale. Social problems have arisen, where the initial allocation of rights is biased towards the polluter (Coase 1960), inertia prevents groups from acting in the common good (Ciriacy-Wantrup and Bishop 1975) or where groups including the environment (Quiggin 2001), impoverished sections of society or future generations (Bromley 2007) and/or indigenous peoples (Nikolakis et al. 2013) are excluded from market participation. Political barriers may also arise where: supply scheduling, capacity or natural scarcity transition rapidly between elastic and inelastic states (Randall 1981); policy-phasing fails to understand the hydrological realities including incomplete knowledge of future water supply and variability (Loch et al. 2014); adopted instruments send different signals in their implementation or co-implementation (Lago et al. 2015); there is a lack of clear policy objectives and political buy-in at all levels (Castle 1978); prior policy investments (lock-in costs) determine the current public and private investment options in river basin management (Garrick et al. 2013); and/or there is a lack of institutional support, funding or enforcement of rules (Garrick and Aylward 2012). As a result, in cases, where economic instruments have been implemented, society may still be worse off if the costs (including the transaction costs) of implementing these reforms and any residual welfare losses exceed the revenue (if any) obtained from adopting economic instruments.

In this paper, we examine how economic instruments to achieve welfare-enhancing water resource outcomes can realize their full potential in basin-scale management contexts. After developing a basic framework in the next section, we use it to review the literature on water markets, charges, efficiency subsidies and voluntary agreements. We suggest that the adoption of economic instruments can only be the outcome of social decision processes resulting from the influence of interest groups. Without clear rules and regulations underpinning interaction within a river basin, the negative externalities (e.g., low allocations to the environment) associated with the actions of one group (i.e., those overusing a resource) will not be addressed (Laffont and Tirole 1991). Managing water at the basin scale therefore implies assigning economic instruments to a distinctive role within the relevant policy framework, such that they achieve the greatest collective good consistent with the fundamental social- and political-welfare questions discussed above.

\section{Water Realpolitik: Settling for Second-Best Options}

\subsection{Public transaction costs as a basis for economic instruments}

The implementation of relevant political and institutional reforms necessary to underpin the process of basin closure is challenging. Arguments for closure will 
inevitably need to be based on objective scientific facts, and institutions may need to be updated or created to deal with water (re)allocation. Arrangements for identifying, quantifying and legitimizing collective objectives for water resource use will be necessary. Planning in support of administering those objectives will also be needed, as will the means to enforce decisions taken through penalizing individuals who do not comply. This is the role of public transaction costs.

Public transaction costs in water (re)allocation include: (i) institutional transition costs to describe, design and implement new arrangements aimed at reorganization, that correspond to an investment phase; and (ii) static transaction costs to administer, monitor and enforce those existing or new arrangements, that correspond to a consolidation phase; where (iii) our choices in both cases are constrained by prior institutional or technological lock-in costs (Marshall 2013; McCann et al. 2005). Engineering approaches may arguably comprise higher production (e.g., capital, operation and maintenance, abatement etc.) rather than transaction costs. But an increasing reliance on economic instruments requires significant transaction costs associated with policy, program and project development or management (Samnakay 2016). Research suggests that, within new water policy in particular, transaction costs represent a major share of the total required investment (Marshall 2013; McCann et al. 2005).

River basin policy often assumes a capacity by individuals and governments to reorganize in order to conserve, preserve and restore ecosystem health (Woolley and McGinnis 1999). Factors such as incomplete information, political entanglement, naïve faith in science and effects of multilevel government all impact on individual or governmental attempts to reorganize successfully (Loch et al. 2014), and can prevent desirable outcomes (Vörösmarty et al. 2010). Yet, the ultimate objective for river basin managers should be to achieve a set of institutional and/or (re)organizational arrangements that: minimize the sum of impacts on transaction costs (Challen 2000); minimize the costs of failing to meet targets (Eggers 2006); monetize and differentiate institutional options for cost-benefit assessments (Krutilla and Krause 2011); or identify the transaction cost-lowering option over time (Marshall 2013). ${ }^{1}$ Whilst easy to specify, these objective functions are difficult (and costly) to achieve. An expanded welfare question following that proposed by

\footnotetext{
${ }^{1}$ The role of the economist as an assessor of policy using cost-benefit analysis to identify an optimised solution is called into question by Bromley (1990), who asserts that politicians are the best arbiters of policy selection, and that only after a selection has been made should economists become involved in the assessment of that policy as an instrument for achieving objectives specified by the collective. This reduces the typical focus on efficiency in favour of effectiveness, where the evaluative criterion becomes one of matching policy decisions and institutional contributions to meeting societies' collective objectives.
} 
Hicks, Kaldor and Pigou above therefore is: how do we best facilitate river basin governance arrangements to keep transaction costs manageable, reduce the risk of future legal challenges, and ensure democratic legitimacy (Huitema et al. 2009)?

Ultimately there appears to be no prescribed set of arrangements that river basin managers can rely on to help them devise lower polycentric arrangements and transaction costs. McCann (2013) asserts that environmental policy design itself should be considered an instrument to reduce transaction costs, and adds a requirement of political acceptability to the list of evaluation criteria; albeit with a focus on static transaction over institutional transition costs. Such views assume a degree of urgency under an increasing recognition that current river basin systems will be challenging to maintain in the face of future climate change-driven variability, which has the capacity to dislocate established distributions of costs and benefits and will likely favor the most politically-important players (Moan and Smith 2007). It is into this context that economic instruments have thus assumed a greater role for global water (re)allocation objectives. However, Marston and Cai (2016) correctly observe that water reallocation is challenging because of a general global lack of suitable and effective institutional capacity. They suggest requisite investments needed to support complex reallocation mechanisms, such as markets or water pricing, may render them inaccessible to many contexts - driving the need for research into non-market reallocation institutional support mechanisms in the future. Thus, there is a requirement to examine economic instruments in more detail.

\subsection{The role of economic instruments}

Where institutional capacity is sufficient, economic instruments may begin to flourish in response to policy requirements. But to date, other than as a means to raise revenue, economic instruments have performed largely a secondary role in water (re)allocation. Prescriptions for full-cost water pricing and tradable water rights, while not uncommon in the literature, are still far from achieving the actual objectives of most water management policies (UN 2016). Hahn's (1989) classic paper suggests that economics and economists may be partially to blame by the way policy-makers follow their advice: "one of the problems with ivory tower theorizing is that it is easy to lose sight of the actual set of problems which need to be solved, and the range of potential solutions” (Hahn 1989: p. 95). Most of the basic normative prescriptions on water pricing and markets are rooted in the first fundamental theorem of welfare economics, which states that competitive markets are an effective means to take advantage of existing welfare improvement 
opportunities among individuals, and that prices can lead to an efficient (re)allocation of resources (Feldman 2008). This implies that allocative-efficiency of water resources requires full-cost-recovery pricing of water including operation, maintenance, capital costs, all other opportunity costs and externalities (Rogers et al. 2002, 1998). Efficient prices will ideally arise as a by-product of well-functioning markets. According to Mendelsohn (2016: p. 1) "the price of water becomes its marginal value. With a market, the marginal value becomes the same for all users and available water is efficiently allocated. ${ }^{2}$ As demand and supply conditions change, the market adjusts the price and the system remains efficient”.

However, more often than not, temporal volatility of water supply creates non-convexity in market prices, while scarcity also creates irreversible consequences for those who cannot afford to meet (high) market prices. Moreover, practical application of the first fundamental theorem of welfare economics to water may transform common pool resources that necessitate coordination (e.g., groundwater) into private goods managed through competition - in turn creating negative impacts (e.g., aquifer overdraft). As the second theorem of welfare economics makes clear, allocative efficiency is not at odds with other socially-relevant criteria. Just the contrary: well-functioning markets guarantee that advances in fairness and policy acceptability are not fulfilled at the expense of economic efficiency. Thus, primary economic claims that prices and markets are appropriate for water (re)allocation may actually be based on incorrect foundations, rather than being constrained by conspicuous obstacles of shifting from abstract recommendations to empirical applications.

Contrary to a significant body of literature (see e.g., Briscoe 1996; Mendelsohn 2016), enacting competitive water prices and effective water markets is more complex than overcoming implementation problems. The advantages of efficient water pricing and trade are based on the logic and principles of market failure (Coase 1960; Demsetz 1967), where public interventions transform externalities and collective concerns into private decisions, and competition efficiently (re)allocates resources. The logic of market failure implicitly assumes that water-use decisions can be decentralized, and that public authorities need only properly define and protect/enforce property rights. Water resources have distinctive characteristics (e.g., public, private and common pool goods; economies of scale and indivisibilities; externalities) that call for dialog between interest groups, in which governance and institutions play a decisive role. Water's distinctive characteristics therefore mean that, when identifying solutions to water challenges, we may first

\footnotetext{
${ }^{2}$ That is, a unique price is set in the market that equals the marginal value of water at its intersection with the supply curve.
} 
look to effective forms of institutions and collective action rather than to moderating individuals' decisions and competition. In other words, water problems such as scarcity, quality degradation, exposure to water-related risk etc. can more readily be interpreted as the outcome of governance, rather than market failure.

Two lines of reasoning are important in this regard: the first one focuses on the nature of water as a distinctive economic good (Hanemann 2006), and the second focuses on the distinctive nature of water management (Ostrom 2010 2007); but both cite the requirement for coordinated (and largely polycentric) governance over competition-focused responses at a river basin scale. The first line of reasoning highlights the very nature of water as an economic good, and requirements for comprehensive management at a river basin scale (Hanemann 2006). Water resources provide an intertwined array of private, public and common pool goods with varied characteristics of non-rivalry and non-excludability. Combined with the 'mobility' of water and the possibility of sequential uses along the hydrological cycle, it becomes difficult for markets and governments to keep track of the myriad positive and negative welfare effects of any alternative use. Water is also distinctive as a heterogeneous commodity that varies relevant to human welfare issues such as time, location, quality and security of supply - making it difficult for prices to reflect these differences in the value of water across time and space. Water is also bulky, costly to store and transport and thus to (re)allocate. As discussed, most historic investments in water development are capital-intensive, with scale economies that can only be harnessed by integrating supply-services and coordinating stakeholders and governments. Water is also essential for life and for maintaining the freshwater, coastal and marine ecosystems that economies and people rely upon. Thus, water decisions imply complex trade-offs. Though not excluding a certain role for prices and trading, these distinctive characteristics necessitate institutions and coordination. Competition and markets are welcome; not as an end, but as an instrument for better coordination and governance.

The second complementary line of reasoning envisages the challenge of water management in designing and implementing non-coercive instruments to trigger collective action (Ostrom 2008, 1990). Under this perspective, water-policy concerns are fundamentally explained as governance, rather than market, failures. Failure comes from not identifying options to reconcile individual water-use decisions with what is in society's best interests - particularly objectives that preserve the resource base and maintain long-term positive welfare and water ecosystem outcomes. Economic instruments can offer non-coercive means to achieve collective objectives; but under this approach, market and pricing schemes should not be assessed on their properties, nor whether they reflect opportunity costs in full or allow for near to perfect competition. Rather, economic instruments 
should be assessed on their capacity to effectively contribute to collective objectives such as managing water scarcity, halting the degradation of water quality, reducing user exposure to droughts and increasing water security in the long-term. ${ }^{3}$ But, we caution that implementing economic instruments as panaceas to cope with complex environmental challenges is unlikely to work. Experience over the last 50 years illustrates the radical failure of promoting isolated water panaceas; whether via strong bureaucracies, water-users' associations or tradable water rights. According to empirical tests conducted by Meinzen-Dick (2007), none of these approaches live up to expectations, and water institutions require continuous improvement in order to adapt their performance to the particular needs of water policy. How then do we ensure effective economic instruments in the management of river basin water resources? In the next two sections, we outline the basis for economic instruments in water (re)allocation, and how they may be applied to overcome governance failure.

\section{Economic Instruments: Welfare-Enhancing Opportunities to Address Water Governance Failures}

Assuming institutional capacity and positive transaction costs, economic incentives for water management are feasible if two basic conditions are met: appropriate rationales for participation, and incentive compatibility (see e.g., Fudenberg and Tirole 1991). The first condition dictates instruments that encourage individuals to engage in a specific action on the premise of subsequent private benefit. The second condition dictates that those individual actions are aligned or made compatible with collective public objectives. Hence, opportunities to use economic instruments exist in situations where: (i) there are welfare-improving opportunities that can be transformed into private benefits for water-users (e.g., economic surpluses from transferring water to more productive uses); and (ii) collective gains then arise in terms of achieving public water policy objectives - a challenging objective to achieve (Rausser et al. 2011). Sensible and conscientious governance are necessary to make these opportunities work for individual users and society alike (OECD 2015). If only private benefits are derived from the instrument, this would not provide opportunities to improve public water outcomes. Rather, the latter can be worsened, as may be evidenced by the erosion of environmental flows in response to the introduction of early water market incentives in Australia

\footnotetext{
${ }^{3}$ The distinctive characteristics of water can make water quality management through economic instruments a "wicked challenge" (Horan and Shortle, 2017). For instance, imperfect substitution between different types of 'bads' (point vs. nonpoint pollution) in emission trading demands the use of uncertainty ratios that are difficult to, and often inappropriately, framed.
} 
(Connor and Kaczan 2013; Delacámara et al. 2015a). Conversely, where only collective gains exist, this may offer positive water (re)allocation opportunities, but an application of economic incentives may not be the most appropriate instrument.

Welfare enhancing opportunities to combine private and collective benefits do exist, and are particularly important for river basins where water is already scarce and further supply development opportunities have been exhausted. Most of these opportunities are the by-product of those same government failures (and successes) that explain current water challenges: decades of supply-oriented measures that have resulted in inefficient water (re)allocation. Opportunities for private and collective benefits can accordingly be classified into four categories, based on the current inefficiencies resulting from past decisions and practice: (i) allocative efficiency gains from transferring water from low to high value uses, places and times; (ii) technical efficiency for water abstraction, treatment, delivery and application in given places and activities; (iii) coordination improvements between relevant water policy domains (e.g., agriculture, energy, land planning, etc.) or between users within the same river basin (upstream-downstream); and (iv) rebalancing current water-uses toward conservation of natural ecosystems to achieve welfare gains from a better preserved environment. The following paragraphs discuss these welfare enhancing opportunities in detail.

Allocative inefficiency in water management is the natural outcome of institutional constraints that preclude the (re)allocation of water to more valuable uses, and encourage water-use with low marginal values and high opportunity costs. For example, when property rights cannot be exchanged through voluntary agreements ${ }^{4}$ or markets, agents often face a 'use it or lose it' trade-off dilemma. In extreme cases, not using the water right may lead to its cancellation. Evidence of gaps in the value of water across uses, places and times is a powerful argument to expose the potential of transfers to enhance the allocative efficiency of water through mutually-beneficial agreements among water-users. However, caution should be exercised when developing opportunities for resource reallocation among private users. Evidence shows that efficiency-focused approaches which do not explicitly and actively pursue collective gains often lead to water overuse, the depletion and pollution of water bodies, inequitable utilization of the resource

\footnotetext{
${ }^{4}$ In European countries like Italy, early drought is often managed through voluntary agreements among users, who are given the chance to decide where and how much water withdrawals will be reduced. Although the instrument is reported to be more efficient in mitigating welfare losses as compared to command-and-control approaches, its effectiveness is limited when droughts aggravate (Santato et al. 2016).
} 
and degraded riverine and related ecosystems under reduced return-flows (see e.g., Delacámara et al. 2015a).

Multiple welfare-enhancing opportunities are linked to bridging the technical efficiency gap, which refers to water-uses across different purposes and, in particular, potential water savings from using the best available technologies. However, once an efficiency gap has been identified, it is also important to understand why water-users do not choose to bridge this gap privately, and thus whether water policy based on supporting (subsidizing) efficiency improvements may be the best approach for correcting under-adoption. Failure to privately adopt efficiency improvements can be partially explained by typically-adopted public incentives such as low tariffs, subsidies, use it or lose it property rights, openaccess arrangements, and/or poor enforcement programs. A risk with technological efficiency improvements may be, paradoxically, an increase in total water consumption. This may stem from a failure to align governance and efficiency outcomes (Gómez and Pérez-Blanco 2014), or where third-party impacts/benefits such as return-flows and drainage are incorrectly specified (Adamson and Loch 2014). Welfare-expansion can also come from coordination improvements in water decisions at: the nexus between sectors such as food, water, energy and climate change; places within the same catchment (upstream and downstream) or moments of time (dry and rain season); and/or the (re)distribution of cooperation benefits to enforce water-sharing or management agreements. This may be achieved through the application of more appropriate forms of polycentric governance coordination across and within policy-making parties (Garrick et al. 2012).

Finally, an increasing set of welfare-expansion opportunities are linked to rebalancing water-use towards ecosystems in order to reap the benefits of betterpreserved water resources, and improvements in water quality (e.g., recreational amenities, health benefits and urban regeneration - but also enhanced productive processes). Integrated water resource management is based on the presumption that these benefits outweigh opportunity costs; assuming restoration takes a cost effective route (EC 2000). Functions traditionally performed by natural systems such as filtration, storage or runoff regulation may offer more cost-effective, noregrets approaches to the management of pollution, controlling weather extremes and reduced exposure to risk when compared against conventional grey (i.e., concrete) infrastructure (WWAP - UNESCO 2012). Despite a substantial body of research indicating potential benefits (Mazza et al. 2011; Naumann et al. 2011), a lack of long-term data and consistency in monitoring and valuation have largely prevented the widespread adoption of these solutions in decision-making processes, inhibiting wider uptake by risk-averse decision-makers and investors. To address this problem, several countries are now in the process of releasing 
strategies to foster an increased implementation of nature-based solutions (EC 2013).

Thus, in general terms, appropriate water policy involving economic instruments does not simply involve the engagement of individuals to reap private and public benefits. Rather, it provides opportunities for private individual actions to contribute to public river basin policy objectives. However, for these incentives to work, policy-makers must clearly identify their objectives, be able to predict individual responses, and be aware of the hydrological limitations of the river basin. This constrained-welfare framework allows for both the institutional goals to be realized at least-cost, and the maximizing of returns from private uses whilst preventing water-use that exceeds system capacity — consistent with the Hicks, Kaldor and Pigou welfare question we originally raised. Next, we discuss practical methods to maximize beneficial river basin policy outcomes from economic instruments.

\section{Making Incentives Work for Managing River Basins}

Institutional inertia may lead to the perception that no new policy instruments are required to harness the potential of opportunities for better river basin management. However, welfare-improving opportunities will exist, and their potential gains are not difficult to measure. Yet, achieving policy/management/collective objectives comprise a necessary condition that will be determined by the incentives and institutions put in place. A working hypothesis is that converting technical, coordination, environmental and allocative efficiency opportunities into effective contributions to river basin management goals requires sensible and conscientious governance to catalyze cooperation among the groups of interest. The delivery and implementation of purposely-designed economic instruments that align users' actions with collective goals and increased social welfare is also required, otherwise these opportunities will be lost. The following sections thus explore how to achieve this goal for select economic instruments.

\subsection{Pricing and charges}

In other areas of the economy, the cost of acquiring a good is determined by the interaction between supply and demand in a market environment, which leads to an equilibrium price that reflects (at least) the cost of producing a marginal unit. The uniqueness of water and the manifold market failures that stem from its management can make this mechanism infeasible, and often undesirable.

Water prices represent a levy on use (i.e., a charge), which typically serves to recover (part or all of) the costs associated with the infrastructure necessary to 
convey the resource to users (construction, operation, maintenance and future refurbishment allowances). The full resource cost of water (i.e., the difference between the value of realized use and that of the next best-relinquished water-use) and environmental costs (aquatic ecosystem deterioration and depletion caused by a particular water-use) is rarely recovered. Although insufficient evidence on the biophysical processes linking the environmental status of water bodies to ecosystems health complicate the definition of accurate environmental charges (Finlayson and Cruz 2005), major challenges stem from barriers to political acceptability (EEA 2013). Moreover, charges are often decoupled from water-use (e.g., payment per hectare of irrigated crops), spatial and temporal variations in water availability are rarely accounted for, and pricing for different users can be disparate (i.e., related to ability to pay disregarding use characteristics, as shown by the gap in urban and agricultural water-use cost-recovery levels). These features undermine incentives for use rationing, and may contribute to overexploitation (EEA \& OECD 2013; OECD 2014).

Yet, where the critical institutional transition and static transaction costs discussed above are fully accounted for, charges can represent a powerful instrument to balance private benefits with collective objectives (Dinar and Subramanian 1997; Tsur and Dinar 1997). Given a demand function characterized by productive users' willingness to pay for a marginal unit of water, institutions can adjust charges to determine the amount of extraction and resulting environmental flows at any (site-specific) location and moment in time (permanent and incremental charges). ${ }^{5}$ Higher charges strengthen the participation constraint, and contribute to water policy objectives through reduced use or higher cost-recovery - provided revenues are earmarked for water conservation-related policies (Kampas et al. 2012; Pérez-Blanco et al. 2016). When river basins are closed, charging resource costs to water-users can also result in a more efficient market allocation, penalizing those that are less productive and allowing for the entrance of more productive users (Berrittella et al. 2007). Again, sensible and conscientious governance is necessary here in order to prevent the realization of private welfare-enhancing opportunities that lead to additional pressure on scarce water resources.

There is also a significant body of literature questioning the ability of water charges to limit extraction in some water-scarce and drought-prone settings, where the value of water is higher and demand is inelastic (recent examples can be found in Berbel and Mateos 2014; Pérez-Blanco et al. 2015). In highly water-scarce contexts, marginal willingness to pay (e.g., by agriculture) is increased, and higher

\footnotetext{
${ }^{5}$ In drought-prone and water contexts with inelastic agricultural water demand, balancing supply and demand, through incremental charges may require high charges that are politically unfeasible.
} 
charges can lead to significant income losses in water-intensive economic sectors (e.g., irrigation), while doing little to improve environmental outcomes. Some authors have claimed that charges are useless for achieving sustainability under these conditions (Berbel and Mateos 2014). Yet, pricing can enhance positive welfare outcomes when water demand response is inelastic. For example, in nonallocative-efficient closed river basins where unrealized water-uses that can outperform existing applications are ignored, and status quo water-uses persist due to low levels of cost-recovery and water charges, charges can be leveraged against the high willingness of users to pay increased cost-recovery ratios. This will raise revenue to fund activities that both enhance participation and contribute to the achievement of collective goals (e.g., payment for ecosystem services). Alternatively, if water demand is elastic and higher charges lead to a reduction of water extractions and private income, revenue-raising can be used to compensate the losses of individuals supplying valuable ancillary benefits (e.g., landscape management, cultural values). Affordability is thus addressed through separate measures decoupled from water-use, such as lump-sum subsidies or payment for ecosystem services, instead of the reduction of water price incentives (EEA 2013). EU water and agricultural policy are inspired by this approach: water policy encourages (although does not enforce) full cost-recovery charging (EC 2000), while the recently reformed Common Agricultural Policy relies mostly on direct payments, of which $30 \%$ have to be 'green payments' related to ecosystem services (OJ 2013).

\subsection{Technical efficiency improvements}

Taking advantage of opportunities to enhance the technical efficiency of water extraction, storage, transportation, distribution and application has predominantly been done by relying on existing instruments and institutions. Most policies aimed at saving water via updated or new techniques focus public effort on overcoming the participation constraint; typically by subsidizing the shift to better technology, and taking the incentive compatibility for granted. That is, priority is given to deliver upgrades while the importance of incentives for contributing to river basin management objectives are overlooked, if not ignored entirely. However, failure to properly incorporate incentive compatibility into technically-efficient economic instruments will ultimately see those instruments themselves fail.

Higher technical-efficiency and welfare gains may not equate to water savings or resource gains for a river basin. An increasing body of research shows how unmanaged incentives can make water saving measures fail; particularly in the irrigation sector where modernization plans are often publicized as 'water 
panaceas'. Analytical models show that final water extraction and consumption following technical improvements are a function of three factors, namely: (i) higher technical efficiency; (ii) application costs which typically increase with more modern devices; and (iii) higher productivity per unit of water (Gómez and Pérez-Blanco 2014). While the first two factors reduce extraction and consumption, higher productivity of water creates new welfare opportunities that private users can exploit at the expense of third-parties and the environment (including double-cropping, more water intensive crops, or expansion of irrigated acreage). If the latter outcome prevails, irrigation modernization may lead to higher consumption, lower return-flows and aquifer replenishment, and reduced water availability for other uses downstream - although water-use may actually fall (the so-called hydrological paradox). Hydrological paradox outcomes have been reported in several regions worldwide, including areas of the US (Pfeiffer and Lin 2014; Ward and Pulido-Velazquez 2008), Europe (Rodríguez-Díaz et al. 2012) and India (Msangi and Cline 2016). In other cases, the productivity effect may be overwhelming and lead to behavioral changes that increase both water consumption and total extraction, as reported by Loch and Adamson (2015) for Australia. The hypothesis that, under certain conditions, an increase in technical efficiency may lead to an increase in the overall use of a resource is well known in economics, and has received different names such as the Khazzoom-Brookes Effect or the Jevons' Paradox (Alcott 2008, 2005; Khazzoom 1989).

Even in those cases where paradoxes are not observed, incentive compatibility may not be achieved. This can be evidenced in the case of subsidized technical improvements that stabilize demand, but fail to reduce consumption. For instance, Berbel et al. (2014) assess the outcomes of a heavily-subsidized irrigation modernization program in southern Spain and report a decrease in water extraction together with a negligible increase in consumption. However, since consumptive use is not reduced, any water saving exists only on paper. The 'exceedance' water resources allocated to the environment are simply the return-flows and aquifer percolation that resulted from earlier inefficient irrigation devices, now reallocated. From our perspective, incentive compatibility can only be justified where the benefits from the reallocation policy or projects outweigh the costs. This can be achieved through qualitative improvements (e.g., a decrease in nitrate loads that improve water quality), the restoration of valuable services (e.g., critical ecosystem services supplied by reallocated irrigation water), and reclaiming non-recoverable runoff/percolation. One such example can be found in the investments conducted in the San Joaquin River in California to minimize drainage water from irrigation, and thus reduce high selenium, boron and salt loads (Linneman et al. 2014). However, in most cases, these collective benefits are typically not measured 
and there is little evidence on the actual contribution of technical efficiency improvements.

Additionally, under specific conditions, subsidized technical improvements can actually strengthen the participation constraint. For example, more efficient irrigation networks increase the need for complementary inputs such as energy for sprinklers and irrigation control, and labor (Corominas 2010; Rodríguez-Díaz et al. 2012). Higher irrigation costs may erode individual incentives to engage in irrigation and save water, in particular when water prices are relatively low compared with competitive labor and energy prices. Barriers to participation may be also triggered if no public subsidies are in place and full-cost recovery is applied. Since the technical shift involves a change in the incentives, users are unlikely to continue making the same decisions as before. Assuming that water savings are directly proportional to the improvement in the technical efficiency is misleading, and can make (often heavily) subsidized technical improvements backfire. Previous research reports that higher (or similar) water extraction and consumption levels following technical efficiency improvements are more likely to happen when irrigated land can be expanded, the water constraint is binding (fallow land, deficit irrigation), the know-how to introduce water intensive crops is in place, and the efficiency of previous infrastructure is significantly lower. On the other hand, reducing water rights or constraining irrigated land when water accounting is insufficiently developed, removing harmful subsidies (e.g., energy subsidies that reduce application costs) and increasing the price of water can potentially mitigate water demand increases triggered by higher water productivity (Berbel et al. 2014). Integrating technical efficiency improvements into river basin management objectives thus requires careful consideration of how the welfare of individuals interacts throughout the hydrological system, and matching the use of complementary economic instruments with the capacity to transform potential savings into contributions to reduce water scarcity, drought risk or meet any other policy objective. Overall, without complementary instruments, an increase in irrigation efficiency makes water a more productive input and may result in an increase in, rather than a reduction of, water extraction and consumption.

\subsection{Cooperative agreements}

Cooperative agreements are incentive-based voluntary arrangements negotiated among parties for the adoption of practices that contribute to water policy objectives (Lago et al. 2015). The economic incentive can be of a pecuniary (typically through a subsidy) or non-pecuniary nature (community recognition of private efforts). The former are known as Payment for Ecosystem Services (PES) and are 
frequently used to make farmers adopt practices that are expected to enhance the quantitative and/or qualitative status of water bodies. The latter include Voluntary Agreements (VA) based on non-pecuniary economic incentives that make use of existing welfare enhancing opportunities to align individual decisions with collective goals. ${ }^{6}$ Economic incentives exclude voluntary arrangements that are the direct consequence of a regulation; for example, Drought Steering Committees in Europe (see e.g., JRBA 2005; PRBA 2003).

PES involve a bidirectional wealth transfer, in which water policy objectives come at the expense of financial compensations paid to water-users (beneficiarypays principle). The accomplishment of PES is conditioned to the ability of institutions to define payments consistent with the shadow price of water across uses, time and space. In the case of water resources, principal-agent problems are often characterized by relevant information constraints and asymmetries that can lead to outcomes that are ineffective (low participation), costly (large information rents), or both (Iftekhar et al. 2013; Zuo et al. 2015). The latter was the case of the Special Plan of the Upper Guadiana in Spain, which targeted the restoration of upstream Guadiana River aquifers through an investment of EUR 5.5 billion (of which EUR 3 billion was ultimately approved) to reduce pumping by $200 \mathrm{hm}^{3} /$ year. Limited water accounting capacity led institutions to buy back water rights worth EUR 66 million through the purchase of agricultural land, resulting in the acquisition of $2 \mathrm{hm}^{3}$ of actual water and a larger volume of paper rights (13.3$13.6 \mathrm{hm}^{3}$ ) (Fernández-Lop and Hernández Herrero 2013).

When shadow-price estimates can be more accurately obtained, PES can be an effective coordination tool to restore ecosystem services. PES have the ability to overcome resistance from users and unblock transition (Crase et al. 2013; Marshall 2013), offering an edge on solutions based on the polluter-pays principle (PPP) (e.g., charges). Yet, better coordination and improved ecosystem services through PES come at the expense of a (significant) burden on the public budget. In the Murray-Darling Basin in Australia, the presence of water markets notably reduced information constraints, yet the expenditure on water buyback programs still totaled AU\$2.3 billion to acquire 1500 gigaliters over a five-year period (DoEE 2016). Another constraint for the implementation of PES is legal in nature. In some legal settings (e.g., in the EU), the beneficiary-pays principle has been adjudicated

\footnotetext{
${ }^{6}$ In this definition, we include negotiated agreements among government authorities and/or private parties to achieve environmental objectives through the use of incentives that are "truly voluntary" and go "beyond compliance to regulated obligations" (i.e., rewards or penalties) (Lago et al. 2015). Examples can be found in the collective action Spanish and Italian watershed boards implement to reduce allocation during droughts (García-Mollá et al. 2013; Santato et al. 2016).
} 
against, arguably making $P P P$ closer to a principle than a rule (Lindhout et al. 2014). Although this has not prevented low cost-recovery ratios or the implementation of buyback schemes in Europe, the apparent mismatch between legal principles and realpolitik is being addressed by significant European research initiatives to improve the understanding of biophysical processes, value ecosystem services, and accurately charge uses that modify these outcomes (see e.g., Notte et al. 2012).

Contexts in which a successful VA may be accommodated can be difficult to find. The competitive nature of markets makes it challenging to find unexploited opportunities for individual profit, especially if these opportunities also need to generate collective gains. Room for VAs can be found in the literature on naturebased solutions, which portray an ample range of green technologies with low uptake that can help improve the environmental status of water bodies, while outperforming available engineering technologies (Baro et al. 2015; Gómez et al. 2014). Due to persistent uncertainty not only on the actual performance of the technology (lack of long-term data and consistency in monitoring), but also on institutional and legal frameworks, mainstream adoption of nature-based solutions has proved challenging. In this context, VAs between public and private enterprises can help reduce information constraints and uncertainty, and lead to successful partnerships that enhance private benefits while creating collective gains. National and supranational strategies for the implementation of green infrastructures and other nature-based solutions will play a relevant role in this regard, paving the role for higher legal and institutional certainty and the development of successful VAs among private and public enterprises (EC 2013).

\subsection{Water trading}

Water trade is by far the most complex and challenging of economic instruments to design, implement and sustain over time. However, water trading is an effective way for fully-aware buyers and sellers to reallocate water through voluntary and mutually-beneficial agreements. This increases and/or ensures the production of goods and services, and makes water exchange a convenient instrument to promote different economic activities (Young 2010). Theoretically, a perfectlyfunctioning market free from government interference allows for the efficient (re)allocation of resources, leading to optimal outcomes. In this "efficient equilibrium state, the resource costs, opportunity costs and social costs are equal at the margin, and they are all equal to the price of water" (Randall 1981: p. 197). Such optimal economic development objectives, rather than water management goals, were the main driver in the original adoption of many current water trading schemes (Howe 2000). 
Apart from the interest of potential buyers and sellers, the real opportunity of water trading lie on its potential to obtain benefits for water policy objectives. Thus, as a means to an end, water trading should not be judged simply by its financial performance (be it volume of water traded or prices), but also according to its effective contribution to curb scarcity, reduce drought-exposure, meet water quality standards and increase economic resilience and/or adaptability (Quiggin 2012). In other words, from a river basin perspective, the key to designing and implementing a water trade scheme arises from transforming good business opportunities for those directly involved in the bargain, into good water governance outcomes for everyone. Therefore, when designing economic instruments, policy-makers should understand the behavioral responses to these instruments so that water-users don't over-invest in systems that prevent their ability to trade and expose capital to undue risk (Adamson and Loch 2014).

Trade can contribute to water policy objectives by improving water allocation among market activities that enhance the potential of the economy to increase the provision of goods and services within the range of existing water resources, given water quality requirements. This is the case for water markets in Australia, Chile and western USA, although some literature suggests the effect is more limited in the latter two cases (Garrick et al. 2009; Grafton et al. 2011). Water trade can also improve water-user adaptability by making water allocation contingent to available resources in order to reduce welfare losses and provide a better response to droughts (Crase and Gawne 2011; Loch et al. 2012). An example of this is, replacing water licenses with shares that allow holders to use a proportion (instead of a fixed amount) of allotments in Australian water markets (Young 2014). Markets can further reallocate water-user risks, so that the vulnerability of wateruses exposed to scarcity and droughts is diminished, as was evident in Australia during the Millennium drought where perennial crops were kept alive by forgoing annual crop opportunities (Loch and Adamson 2015). Conveying incentives for water conservation and pollution abatement through the more immediate awareness of water's value on a market is a significant benefit from trade arrangements; even though evidence shows that, if not complemented with sensible governance, the actual outcome of markets can be the opposite (Ciriacy-Wantrup and Bishop 1975; Quiggin 2001). This may be offset by providing an alternative to traditional approaches to water management that discourages costly and potentially regrettable investments (Kates et al. 2012; Mazza et al. 2011), for instance through unbundled property rights systems that fully assign the investment risk to shareholders (Young 2015). Finally, markets make clear to water-users, interest groups and institutions the opportunity costs (i.e., those associated to foregone alternative choices) of some of their decisions (Delacámara et al. 2015b). This is a primary 
objective for water banks, which institutionalize water trading through an intermediary administrative agency acting between buyers and sellers (see e.g., Montilla-López et al. (2016) for a review of international experiences with water banks).

Assuming zero-transaction costs, opportunities to reallocate water to its most productive uses exist when the value of water is variable across water-users. This is the approach generally followed to identify the potential of water markets (Rey et al. 2011). However, transaction costs matter (as we have shown above), cannot generally be assumed away at zero-levels, and affect how much water can be transferred within and between river basins. This is especially true when we take into account all environmental constraints and possible costs (i.e., opportunity costs, costs from transport and interim losses due to infiltration and evaporation, and transaction costs including institutional and neoclassical or market exchange/ transfer costs). Evidence shows that, even under the spurious assumption of zerotransaction costs, opportunities for water trade decay in relation to the number of water bodies involved and delivery distances as transport costs increase (Delacámara et al. 2015a). Further, from a social perspective, a key question is whether the best interests of market-contracting parties also represent the best interests of all other parties potentially affected by the spatial (re)allocation of water in response to new policy objectives. This implies taking into account all opportunity costs, including any third-party and indirect socio-economic effects associated with former water-uses. For example, if unaccounted for, technical efficiency gaps between users can increase consumption and reduce environmental flows - the case of the interconnected Tagus and Segura basins in Spain (Rey et al. 2016). Major transactions like this can also affect commercial income beyond the agricultural sector (e.g., food processing industries) through substantial, uncompensated economy-wide impacts. Accounting for water consumption, instead of diversions, could address the problem - although it would likely increase transaction costs and reduce gains from trade (Connor and Kaczan 2013). Further, operationalizing water markets requires significant payments to transform the allocation regime, that may strain public budgets (Garrick and Aylward 2012).

Restoring incentive compatibility to allow water trade to achieve collective objectives requires accounting for externalities and third-party effects at the river basin scale; else deep and competitive markets may become a driving force of water scarcity, instead of an instrument for water conservation. Too much attention has been focused on defining property rights for efficient trade, and far less on identifying the transactions that may be environmentally-neutral once all sideeffects have been taken into account. In water-stressed areas, the scope for trade shrinks notably when, beside private gains, incentive compatibility constraints are 
brought into the picture; for instance through in-kind taxes on trade to keep water consumption at similar, or even lower, levels, in order to enhance environmental flows (Gómez et al. 2013). The effect of making these caveats over water costs will be higher the larger the technical efficiency gap, since the interests of more groups can be affected leading to larger opportunity and transaction costs (Rey et al. 2011). General reviews of experience to date with water trade suggests that these effects have not been taken into account (Hanak et al. 2011; Young 2010). Rather, they are often overlooked along with environmental impacts in particular. Furthermore, although limits to water rights are legally defined, managers do not enjoy complete understanding of possible contingencies or comprehension of the multiple ways that water-use and diversion decisions might affect the choice portfolio of third-parties, and/or the environmental services potentially delivered by water to ecosystems along an entire river basin (Howe 2000).

If collective action through cooperation among relevant interest groups is put in place to complement individual incentives, water trade can be highly instrumental in aligning individual actions with multiple relevant collective objectives for water resource management; especially in water-scarce and drought-prone river basins. The main implementation challenge, apart from the considerable institutional capacity and investments needed to establish an sustain markets, concerns adapting the typically pervasive business opportunities that may stem from the ability to trade water with the more intricate (and potentially less politically-defensible) policy objectives of water conservation, drought risk reduction, quality improvements, etc.

\section{Discussion and Conclusions}

Imbalances between water supply and demand are costly not only for the environment but also for private users. For instance, an average of EUR 6.2 billion of market income has been lost yearly to water shortages in the EU since 1980, and this figure does not account for indirect impacts or persistent losses to structural scarcity (Strosser et al. 2012). A better (re)allocation and management of water resources can mitigate the impact of droughts and scarcity on production, and also contribute to achieving public policy goals. However, strategies to tackle water insecurity have largely failed to create meaningful incentives that align private interests and collective goals - the basic foundation needed to enforce the measures and recommendations that good water policy puts forward.

The conceptual framework presented in this paper has been used to assess the role of economic instruments in contributing to private (participation) and public policy (incentive compatibility) goals, and the development of alternatives to 
reshape them so that they enhance their performance in the context of water scarcity and drought management. A key lesson to be drawn from our analysis is that economic instruments are context-specific, and their contribution is conditioned to the objectives they were designed to address - be it a better environmental status, (allocative) efficiency, affordability, no-regrets outcomes (meaning that the instrument is reversible and/or useful even if does not address the intended impacts), fairness (based on compliance with the PPP), or a combination of all of these. Sensible sequencing and thoughtful use of synergies at a micro-, meso- and macro-economic level is a prerequisite to the development of a policy mix that fully exploits available welfare-enhancing opportunities. For example, the combination of water markets and pricing/charges can increase economic surplus, enhance users' ability to pay through gains from trade, and incentivize lower water-use through higher costs; potentially while complying with the PPP. On the other hand, the implementation of markets may demand substantial investments in physical infrastructure and institutional transaction costs, and thus be challenging to revert in cases where design failures arise, and higher costs displace low-income farmers leading to inequitable outcomes. The realization and amplitude of these outcomes are context specific in time, space and institutional setup terms.

Economic instruments build on significant advances in social science research, which make it increasingly feasible to address persistent problems of a social, political, economic and institutional nature. Bridging the gap between our understanding of hydrological and socioeconomic processes offers the opportunity for better communication between all of these parties. However, perhaps unsurprisingly, the intricate implementation of economic instruments may have moved attention away from the problems they are designed to solve, and instead placed it squarely upon the instruments themselves. As we have shown here, full-fledged economic instruments rooted exclusively on the first welfare theorem of economics are insufficient to resolve water management problems which largely stem from the coordination and institutional challenges of managing the multiple uses of a complex asset like water.

Yet, where we substitute conventional notions of command-and-control and centralized planning for economic instruments with implicit incentives, motivation and multi-level governance arrangements, we may facilitate the development of management solutions that also contribute to water policy objectives. This paper identifies the welfare-enhancing opportunities possible in water resource management through the adoption of various economic instruments, and assesses how to leverage them to improve allocative efficiency while balancing private and collective income. We argue that from an integrated water resources management perspective, economic instruments are but a means to an end and must be judged 
based on their ultimate contribution to private and public policy goals. Any analysis must go beyond the boundaries of simple balances between costs and benefits to instead rely on bounded-rationality frameworks that make the best possible use of the existing information. However, we also advocate applying precautionary principles to carefully examine alternative courses of action, so as to discard those posing a higher probability of resulting in negative outcomes. Thus, rather than favoring one instrument over another, we warn against the historical failure of seeking water panaceas that promote the use of a single instrument in isolation.

Economic instruments are not only creatures of design but also of context. Their role cannot be understood in isolation, but rather as an integral part of the policy mix and the institutional and socioeconomic background in which they take place. Conversely, the performance of other (economic) instruments within the policy mix is also conditioned by existing arrangements, calling for a careful assessment of spill-over effects not limited to water policy and users, but including synergies across related policies and economic sectors. Much research is still needed to understand the dynamics of the so-called nexus; putting in place economic instruments based not only on competition but also on cooperation is but a prerequisite to fully exploit their welfare-enhancing potential.

\section{Acknowledgement}

This paper is the outcome of the collaborative effort of research teams from the EU and Australia. This research received funding from the European Commission through the H2020 project AQUACROSS (Knowledge, Assessment, and Management for AQUAtic Biodiversity and Ecosystem Services aCROSS EU policies) - the Climate-KIC Europe - through the Climate Smart Agriculture Booster project AGRO ADAPT (Service for local and economy wide assessment of adaptation actions in agriculture), the Australian Research Council - through grants DE150100328 (Transaction costs of Murray-Darling Basin water reform) and DE160100213 (Optimising national benefits from restoring environmental water flows), and the University of Adelaide EU Centre for Global Affairs - through grant Building lasting collaborative arrangements on water scarcity management between Australia and the EU.

\section{References}

Adamson, D and A Loch (2014). Possible negative feedbacks from "gold-plating" irrigation infrastructure. Agricultural Water Management, doi: 10.1016/j.agwat. 2013.09.022. 
Alcott, B (2008). Historical overview of the Jevons paradox in the literature, In The Jevons Paradox and the Myth of Resource Efficiency Improvements, pp. 7-78. London: Earthscan.

Alcott, B (2005). Jevons’ paradox. Ecological Economics, 54, 9-21. doi: 10.1016/j.ecolecon.2005.03.020.

Baro, F, E Gómez-Baggethun, J Hauck, L Kopperoinen, C Liquete and P Potschin (2015). Green infrastructure, In OpenNESS Ecosystem Service Reference Book. M Potschin and $\mathrm{K}$ Jax (eds.).

Berbel, J, C Gutiérrez-Martín, JA Rodríguez-Díaz, E Camacho and P Montesinos (2014). Literature review on rebound effect of water saving measures and analysis of a Spanish case study. Water Resources Management, 29, 663-678. doi: 10.1007/ s11269-014-0839-0.

Berbel, J and L Mateos (2014). Does investment in irrigation technology necessarily generate rebound effects? A simulation analysis based on an agro-economic model. Agricultural Systems, 128, 25-34.

Berrittella, M, AY Hoekstra, K Rehdanz, R Roson and RSJ Tol (2007). The economic impact of restricted water supply: A computable general equilibrium analysis. Water Resources, 41, 1799-1813. doi: 10.1016/j.watres.2007.01.010.

Briscoe, J (1996). Water as an economic good: The idea and what it means in practice. Presented at the World Congress of the International Commission on Irrigation and Drainage, Cairo (Egypt).

Bromley, DW (2007). Environmental regulations and the problem of sustainability: Moving beyond “market failure.” Ecological Economics, 63, 676-683. doi: 10.1016/ j.ecolecon.2007.02.008.

Bromley, DW (1990). The ideology of efficiency: Searching for a theory of policy analysis. Journal of Environmental Economics and Management, 19, 86-107. doi: 10.1016/ 0095-0696(90)90062-4.

Castle, EN (1978). Property rights and the political economy of resource scarcity. American Journal of Agricultural Economics, 60, 1-9. doi: 10.2307/1240155.

Challen, R (2000). Institutions, Transaction Costs, and Environmental Policy: Institutional Reform for Water Resources. Northampton MA: Edward Elgar Publishers.

Ciriacy-Wantrup, SV and C Bishop (1975). Common property as a concept in natural resource policy. Natural Resources Journal, 15, 713-727.

Coase, RH (1960). The problem of social cost. The Journal of Law and Economics, 3, $1-44$.

Connor, JD and D Kaczan (2013). Principles for Economically efficient and environmentally sustainable water markets: The Australian experience. In Drought in Arid and Semi-Arid Regions, K Schwabe, J Albiac, JD Connor, RM Hassan and LM González (eds.), pp. 357-374. Netherlands: Springer.

Corominas, J (2010). Agua y energía en el riego, en la época de la sostenibilidad. Ing. Agua 17, 219-233.

Crase, L and B Gawne (2011). Coase-coloured glasses and rights bundling: Why the initial specification of water rights in volumetric terms matters. Economic Papers: A Journal of Applied Economics and Policy, 30, 135-146. doi: 10.1111/j.17593441.2011.00102.x. 
Crase, L, S O’Keefe and B Dollery (2013). Talk is cheap, or is it? The cost of consulting about uncertain reallocation of water in the Murray-Darling Basin, Australia. Ecological Economics, 88, 206-213.

Delacámara, G, CM Gómez and J Maestu (2015a). Water trading opportunities and challenges in Europe. In K Burnett, R Howitt, J Roumasset and C Wada (eds.), pp. 281-294. Routledge: Routledge Handbook of Water Economics and Institutions.

Delacámara, G, CD Pérez-Blanco, E Ibáñez and CM Gómez (2015b). Water trading in the Tagus River Basin (Spain). In Use of Economic Instruments in Water Policy Insights from International Experience, Global Issues in Water Policy, M Lago, J Mysiak, CM Gómez, G Delacámara and A Maziotis (eds.), pp. 249-263. Berlin: Springer.

Demsetz, H (1967). Toward a theory of property rights. American Economic Reviews, 57, 347-359.

Dinar, A and RM Saleth (2005). Can water institutions be cured? A water institutions health index. Water Science Technology Water Supply 5, 17-40.

Dinar, A and A Subramanian (1997). Water pricing experiences: An international perspective (Report No. WTP386). The World Bank.

DoEE (2016). Progress of water recovery against 2750GL reduction in surface water SDLs (Report). Canberra: Department of the Environment and Energy.

EC (2013). Communication from the Commission to the European Parliament, the Council, the European Economic and Social Committee and the Committee of the Regions: Green Infrastructure (GI) - Enhancing Europe's Natural Capital (Communication No. COM (2013) 249 final., Belgium: European Commission.

EC (2000). Water Framework Directive 2000/60/EC, Council Directive.

EEA (2013). Assessment of cost recovery through water pricing (Report No. 16/2013). Copenhagen: European Environment Agency.

EEA \& OECD (2013). European environment agency-organization for economic co-operation and development database on economic instruments [WWW Document]. http://www2.oecd.org/ecoinst/queries/ (accessed 9.30.13).

Eggers, J (2006). Good governance in der europäischen agrarumweltpolitik: Eine insitutionenökonomische Mehrebenenanalyse.

Falkenmark, M and D Molden (2008). Wake up to realities of river basin closure. International Journal of Water Resources Development, 24, 201-215. doi: 10.1080/ 07900620701723570.

Fernández-Lop, A and E Hernández Herrero (2013). El fiasco del agua en el Alto Guadiana. Presented at the IX Seminario Nacional: Transparencia y Concesiones, Fundación Marcelino Botín, Madrid, Spain.

Finlayson, CM and RD Cruz (2005). Inland water systems, In Millennium Ecosystem Assessment, Conditions and Trends. p. 68. Washington D.C.

Fudenberg, D and J Tirole (1991). Game Theory, 11th Ed, Cambridge: The MIT Press.

García-Mollá, M, C Sanchis-Ibor, MV Ortega-Reig and L Avellá-Reus (2013). Irrigation associations coping with drought: The case of four irrigation districts in Eastern Spain, In Drought in Arid and Semi-Arid Regions, K Schwabe, J Albiac JD Connor RM Hassan AND LM González (eds.), pp. 101-122. Netherlands: Springer. 
Garrick, D and B Aylward (2012). Transaction costs and institutional performance in market-based environmental water allocation. Land Economics, 88, 536-560. doi: 10.3368/le.88.3.536.

Garrick, D, R Bark, J Connor and O Banerjee (2012). Environmental water governance in federal rivers: Opportunities and limits for subsidiarity in Australia's Murray-Darling River. Water Policy, 14, 915-936. doi: 10.2166/wp.2012.120.

Garrick, D, L McCann and DJ Pannell (2013). Transaction costs and environmental policy: Taking stock, looking forward. Ecological Economics, 88, 182-184. doi: 10.1016/j. ecolecon.2012.12.022.

Garrick, D, MA Siebentritt, B Aylward, CJ Bauer and A Purkey (2009). Water markets and freshwater ecosystem services: Policy reform and implementation in the Columbia and Murray-Darling Basins. Special Section: Analyzing the global human appropriation of net primary production - processes, trajectories, implications. Ecological Economics, 69, 366-379. doi: 10.1016/j.ecolecon.2009.08.004.

Gómez, CM, G Delacámara, CD Pérez-Blanco, E Ibáñez and M Rodríguez (2013). Droughts and water scarcity- Tagus (Central Spain \& Portugal) and Segura (SE Spain) interconnected river basins (Deliverable No. 4.3), Work Package 4 - Ex-Ante Case Studies. 7th Framework Contract Project EPI-Water Project (GA 265213).

Gómez, CM and CD Pérez-Blanco (2014). Simple myths and basic maths about greening irrigation. Water Resources Management, 28, 4035-4044. doi: 10.1007/s11269-0140725-9.

Gómez, CM, CD Pérez-Blanco and RJ Batalla (2014). Tradeoffs in river restoration: Flushing flows vs. hydropower generation in the Lower Ebro River, Spain. Journal of Hydrology, 518, 130-139. doi: 10.1016/j.jhydrol.2013.08.029.

Grafton, RQ, G Libecap, S McGlennon, C Landry and B O’Brien (2011). An integrated assessment of water markets: A cross-country comparison. Review of Environmental Economics and Policy, 5, 219-239. doi: 10.1093/reep/rer002.

Grey, D and CW Sadoff (2007). Sink or Swim?: Water security for growth and development. Water Policy, 9, 545-571.

Hahn, RW (1989). Economic Prescriptions for environmental problems: How the patient followed the doctor's orders. Journal of Economic Perspectives, 3, 95-114.

Hall, JW, D Grey, D Garrick, F Fung, C Brown, SJ Dadson and CW Sadoff (2014). Water security. Coping with the curse of freshwater variability. Science, 346, 429-430. doi: 10.1126/science.1257890.

Hanak, E, J Lund, A Dinar, B Gray, R Howitt, J Mount, P Moyle and B Thompson (2011). Managing California's Water: From Conflict to Reconciliation (Report), San Francisco: Public Policy Institute of California.

Hanemann, WM (2006). The economic conception of water, In Water Crisis: Myth or Reality? pp. 61-91. New York: Taylor \& Francis.

Hicks, JR (1939). The foundations of welfare economics. Economics Journal, 49, 696-712. doi: 10.2307/2225023.

Horan, RD, JS Shortle (2017). Endogenous risk and point-nonpoint uncertainty trading ratios. American Journal of Agricultural Economics, doi:10.1093/ajae/aaw088. 
Howe, CW (2000). Protecting public values in a market setting: Improving water markets to increase economic efficiency and equity. The University of Denver Water Law Review, 3, 357-372.

Huitema, D, E Mostert, W Egas, S Moellenkamp, C Pahl-Wostl and R Yalcin (2009). Adaptive Water Governance: Assessing the Institutional Prescriptions of Adaptive (Co-)Management from a Governance Perspective and Defining a Research Agenda. Ecology and Society, 26.

Iftekhar, MS, JG Tisdell and JD Connor (2013). Effects of competition on environmental water buyback auctions. Agricultural Water Management, 127, 59-73. doi: 10.1016/ j.agwat.2013.05.015.

JRBA (2005). Protocolo de actuación en situación de alerta y eventual sequía (Report). Júcar River Basin Authority, Valencia.

Kaldor, N (1939). Welfare propositions of economics and interpersonal comparisons of utility. Economics Journal, 49, 549-552. doi: 10.2307/2224835.

Kampas, A, A Petsakos and S Rozakis (2012). Price induced irrigation water saving: Unraveling conflicts and synergies between European agricultural and water policies for a Greek Water District. Agricultural Systems, 113, 28-38. doi: 10.1016/j. agsy.2012.07.003.

Kates, RW, WR Travis and TJ Wilbanks (2012). Transformational adaptation when incremental adaptations to climate change are insufficient. Proceedings of the National Academy of Sciences, 201115521. doi: 10.1073/pnas.1115521109.

Khazzoom (1989). Energy savings from more efficient appliances. A rejoinder. Energy Journal, 10, 157-166.

Krutilla, K and R Krause (2011). Transaction costs and environmental policy: An assessment framework and literature review. International Review of Environmental and Resource Economics, 4, 261-354.

Laffont, J-J and J Tirole (1991). The politics of government decision-making: A theory of regulatory capture. Quarterly Journal of Economics, 106, 1089-1127. doi: 10.2307/ 2937958.

Lago, M, J Mysiak, CM Gómez, G Delacámara and A Maziotis (eds.) (2015). Use of Economic Instruments in Water Policy, Global Issues in Water Policy. Cham: Springer International Publishing.

Lindhout, PE and VD Broek (2014). The Polluter Pays Principle: Guidelines for Cost Recovery and Burden Sharing in the Case Law of the European Court of Justice (SSRN Scholarly Paper No. ID 2436984). Social Science Research Network, Rochester, NY.

Linneman, C, A Falaschi, JD Oster, K Kaffka and S Benes (2014). Drainage reuse by grassland area farmers: The road to zero discharge. Presented at the Groundwater issues and water management - strategies addressing the challenges of sustainability, US Committee on Irrigation and Drainage, Sacramento (US).

Loch, A and D Adamson (2015). Drought and the rebound effect: A Murray-Darling Basin example. Natural Hazards, 79, 1429-1449. doi: 10.1007/s11069-015-1705-y.

Loch, A, D Adamson and T Mallawaarachchi (2014). Role of hydrology and economics in water management policy under increasing uncertainty. Journal of Hydrology, 518, 5-16. doi: 10.1016/j.jhydrol.2013.10.049. 
Loch, A, H Bjornlund, S Wheeler and J Connor (2012). Allocation trade in Australia: A qualitative understanding or irrigator motives and behavior. Australian Journal of Agricultural and Resource Economics, 56, 42-60.

Marshall, GR (2013). Transaction costs, collective action and adaptation in managing complex social-environmental systems. Ecological Economics, 88, 185-194. doi: 10.1016/j.ecolecon.2012.12.030.

Marston, L and X Cai (2016). An overview of water reallocation and the barriers to its implementation. Wiley Interdisciplinary Reviews, 3, 658-677. doi: 10.1002/ wat2.1159.

Mazza, L, G Bennett, L De Nocker, S Gantioler, L Losarcos, C Margerison, T Kaphengst, A McConville, M Rayment, P Brik, ten, G Tucker and R van Diggelen (2011). Green Infrastructure Implementation and Efficiency (No. Final report for the European Commission, DG Environment on Contract ENV.B.2/SER/2010/0059). Institute for European Environmental Policy, Brussels and London.

McCann, L (2013). Transaction costs and environmental policy design. Ecological Economics, 88, 253-262.

McCann, L, B Colby, KW Easter, A Kasterine and KV Kuperan (2005). Transaction cost measurement for evaluating environmental policies. Ecological Economics, 52, 527-542. doi: 10.1016/j.ecolecon.2004.08.002.

Meinzen-Dick, R (2007). Beyond panaceas in water institutions. Proceedings of the National Academy of Sciences, 104, 15200-15205. doi: 10.1073/pnas.0702296104.

Mendelsohn, RO (2016). Adaptation, Climate Change, Agriculture, and Water. Choices Quarter 3.

Moan, JL and Smith, ZA (2007). Water policy in the western united states: Historical and contextual perspectives, In Environmental Politics and Policy in the West, ZA Smith and J Freemuth (eds.), pp. 173-195. Boulder, CO: University of Colorado Press.

Montilla-López, NM, C Gutiérrez-Martín and JA Gómez-Limón (2016). Water Banks: What Have We Learnt from the International Experience? Water, 8, 466. doi: 10.3390/w8100466.

Msangi, S and SA Cline (2016). Improving groundwater management for indian agriculture: assessing tradeoffs across policy instruments. Water Economics and Policy, 2, 1650027. doi: 10.1142/S2382624X16500272.

Naumann, S, M Davis, T Kaphengst, M Pieterse and M Rayment (2011). Design, implementation and cost elements of Green Infrastructure projects (Final report to the European Commission, DG Environment No. Contract No. 070307/2010/ 577182/ETU/F.1). Ecologic institute and GHK Consulting.

Nikolakis, WD, RQ Grafton and H To (2013). Indigenous values and water markets: Survey insights from northern Australia. Journal of Hydrology, 500, 12-20. doi: 10.1016/j.jhydrol.(2013.07.016.

Notte, AL, J Maes, B Grizzetti, F Bouraoui and G Zulian (2012). Spatially explicit monetary valuation of water purification services in the Mediterranean bio-geographical region. International Journal of Biodiversity Science, Ecosystem Services and Management, 8, 26-34. doi: 10.1080/21513732.2011.645557.

OECD (2015). Water Resources Allocation: Sharing risks and opportunities, OECD Studies on Water. OECD Publishing. 
OECD (2014). Climate Change, Water and Agriculture. Organisation for Economic Co-operation and Development, Paris.

OJ (2013). Regulation (EU) No 1307/2013 of the European Parliament and of the Council of 17 December 2013 establishing rules for direct payments to farmers under support schemes within the framework of the common agricultural policy and repealing Council Regulation (EC) No 637/2008 and Council Regulation (EC) No 73/2009, Regulation.

Ostrom, E (2010). Beyond Markets and States: Polycentric Governance of Complex Economic Systems. American Economic Review, 100, 641-672. doi: 10.1257/ aer.100.3.641.

Ostrom, E (2008). The Challenge of Common-Pool Resources. Environment: Science and Policy for Sustainable Development, 50, 8-21. doi: 10.3200/ENVT.50.4.8-21.

Ostrom, E (2007). A diagnostic approach for going beyond panaceas. Proceedings of the National Academy of Sciences, 104, 15181-15187. doi: 10.1073/pnas.0702288104.

Ostrom, E (1990). Governing the Commons: The Evolution of Institutions for Collective Action. Cambridge: Cambridge University Press.

Pérez-Blanco, CD, G Delacámara and CM Gómez (2015). Water charging and water saving in agriculture. Insights from a Revealed Preference Model in a Mediterranean basin. Environmental Modelling and Software, 69, 90-100. doi: 10.1016/j.envsoft. 2015.03.006.

Pérez-Blanco, CD, G Standardi, J Mysiak, R Parrado and C Gutiérrez-Martín (2016). Incremental water charging in agriculture. A case study of the Regione Emilia Romagna in Italy. Environmental Modelling and Software, 78, 202-215. doi: 10.1016/j.envsoft.2015.12.016.

Pfeiffer, L and CYC Lin (2014). Does efficient irrigation technology lead to reduced groundwater extraction?: Empirical evidence. Journal of Environmental Economics and Management, 67, 189-208.

Pigou, A (1932). The Economics of Welfare, 4th Ed. Basingstoke: Palgrave Macmillan.

PRBA (2003). Protocollo di Intesa (Memorandum of Understanding). Po River Basin Authority, Parma (Italy).

Quiggin, J (2012). Stabilizing the global climate: A simple and robust benefit-cost analysis. American Journal of Agricultural Economics, 94, 291-300.

Quiggin, J (2001). Environmental economics and the Murray-Darling river system. Australian Journal of Agricultural and Resource Economics, 45, 67-94. doi: 10.1111/1467-8489.00134.

Randall, A (1981). Property entitlements and pricing policies for a maturing water economy. Australian Journal of Agricultural and Resource Economics, 25, 195-220. doi: 10.1111/j.1467-8489.1981.tb00398.x.

Rausser, GC, J Swinnen and P Zusman (2011). Political Power and Economic Policy: Theory, Analysis, and Empirical Applications, Cambridge: Cambridge University Press.

Rey, D, A Garrido and J Calatrava (2016). An innovative option contract for allocating water in inter-basin transfers: The case of the Tagus-Segura transfer in Spain. Water Resources Management, 30, 1165-1182. doi: 10.1007/s11269-015-1219-0. 
Rey, L, J Calatrava and A Garrido (2011). Water Market Scenarios for Spain (Deliverable No. WP2 Water Cap and Trade), Water Market Scenarios for Southern Europe: New Solutions for coping with increasing water scarcity and drought risk?

Rodríguez-Díaz, JA, LP Urrestarazu, EC Poyato and P Montesinos (2012). Modernizing water distribution networks: Lessons from the Bembézar MD irrigation district, Spain. Outlook Agriculture, 41, 229-236. doi: 10.5367/oa.2012.0105.

Rogers, P, R Bhatia and A Huber (1998). Water as a social and economic good: How to put the principle into practice. Global Water Partnership/Swedish International Development Cooperation Agency, Stockholm, Sweden.

Rogers, P, R Silva de and R Bhatia (2002). Water is an economic good: How to use prices to promote equity, efficiency, and sustainability. Water Policy, 4, 1-17. doi: 10.1016/ S1366-7017(02)00004-1.

Samnakay, N (2016). Thinking strategically in federal policy: Defining the attributes of high-level policies. Australian Journal of Public Administration, 76(1), 106-121. doi: 10.1111/1467-8500.12199.

Santato, S, J Mysiak and CD Pérez-Blanco (2016). The water abstraction license regime in Italy: A case for reform? Water, 8, 1-15.

Strosser, P, T Dworak, PGA Delvaux, M Berglund, G Schmidt, J Mysiak, M Kossida, I Iacovides and V Ashton (2012). Gap Analysis of the Water Scarcity and Droughts Policy in the EU (European Commission Directorate General Environment, Final report Tender No. ENV.D.1/SER/2010/0049).

Tsur, Y and A Dinar (1997). The relative efficiency and implementation costs of alternative methods for pricing irrigation water. World Bank Economics Review, 11, 243-262.

UN (2016). The United Nations World Water Development Report 2016 (Report). United Nations.

Vörösmarty, CJ, PB McIntyre, MO Gessner, D Dudgeon, A Prusevich, P Green, S Glidden, SE Bunn, CA Sullivan, CR Liermann and PM Davies (2010). Global threats to human water security and river biodiversity. Nature, 467, 555-561. doi: 10.1038/nature09440.

Ward, FA and M Pulido-Velazquez (2008). Water conservation in irrigation can increase water-use. Proceedings of the National Academy of Sciences, 105, 18215-18220. doi: 10.1073/pnas.0805554105.

WEF (2017). Global Risks 2017 (Report No. 12th Edition), Global Risks. World Economic Forum.

Woolley, JT and MV McGinnis (1999). The Politics of Watershed Policymaking. Policy Studies Journal, 27, 578-594. doi: 10.1111/j.1541-0072.1999.tb01987.x.

WWAP - UNESCO (2012). The United Nations World Water Development Report 4: Managing Water under Uncertainty and Risk (Report No. 4), World Water Development Report. World Water Assessment Programme - UNESCO, Paris.

Young, M (2015). Policy note: Doubling the value of water in the American West. Water Economics and Policy, 01, 1571003. doi: 10.1142/S2382624X15710034.

Young, M (2010). Environmental Effectiveness and Economic Efficiency of Water-use in Agriculture, In OECD Studies on Water. Organisation for Economic Co-operation and Development, Paris (France), pp. 1-33. 
Young, MD (2014). Designing water abstraction regimes for an ever-changing and ever-varying future. Agricultural Water Management, 145, 32-38. doi: 10.1016/j.agwat.2013.12.002.

Zuo, A, SA Wheeler, WL Adamowicz, PC Boxall and D Hatton-MacDonald (2015). Measuring Price Elasticities of Demand and Supply of Water Entitlements Based on Stated and Revealed Preference Data. American Journal of Agricultural Economics, 60(3), 442-458. doi: 10.1093/ajae/aav022. 